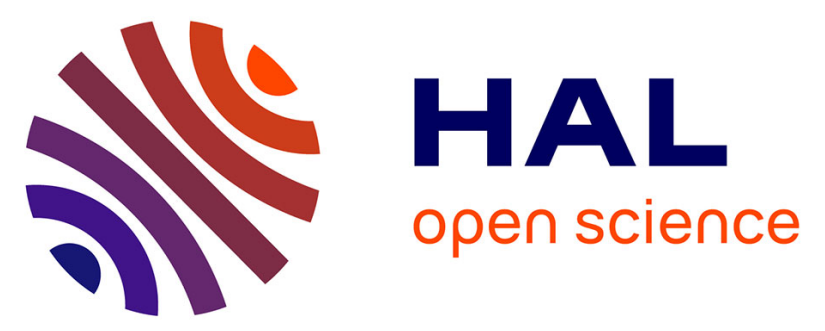

\title{
Ziziphora tenuior L. essential oil from Dana Biosphere Reserve (Southern Jordan); chemical characterization and assessment of biological activities
}

\author{
M.S. S Abu-Darwish, C. Cabral, M.J. J Gonçalves, C. Cavaleiro, M.T. T
} Cruz, M. Paoli, F. Tomi, T. Efferth, L. Salgueiro

\section{To cite this version:}

M.S. S Abu-Darwish, C. Cabral, M.J. J Gonçalves, C. Cavaleiro, M.T. T Cruz, et al.. Ziziphora tenuior L. essential oil from Dana Biosphere Reserve (Southern Jordan); chemical characterization and assessment of biological activities. Journal of Ethnopharmacology, 2016, 194, pp.963-970. 10.1016/j.jep.2016.10.076 . hal-02526475

\section{HAL Id: hal-02526475 \\ https://hal.science/hal-02526475}

Submitted on 31 Mar 2020

HAL is a multi-disciplinary open access archive for the deposit and dissemination of scientific research documents, whether they are published or not. The documents may come from teaching and research institutions in France or abroad, or from public or private research centers.
L'archive ouverte pluridisciplinaire HAL, est destinée au dépôt et à la diffusion de documents scientifiques de niveau recherche, publiés ou non, émanant des établissements d'enseignement et de recherche français ou étrangers, des laboratoires publics ou privés. 


\section{Author's Accepted Manuscript}

Ziziphora tenuior L. essential oil from Dana Biosphere Reserve (Southern Jordan); chemical characterization and assessment of biological activities

M.S. Abu-Darwish, C. Cabral, M.J. Gonçalves, C. Cavaleiro, M.T. Cruz, M. Paoli, F. Tomi, T. Efferth, L. Salgueiro

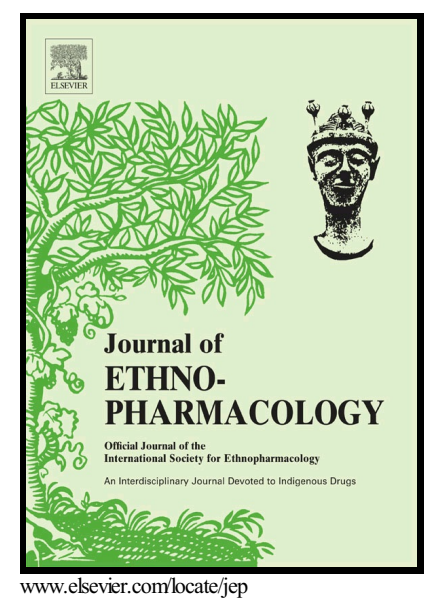

PII: $\quad$ S0378-8741(16)31545-8

DOI: $\quad$ http://dx.doi.org/10.1016/j.jep.2016.10.076

Reference: JEP10534

To appear in: Journal of Ethnopharmacology

Received date: 17 July 2016

Revised date: 12 October 2016

Accepted date: 25 October 2016

Cite this article as: M.S. Abu-Darwish, C. Cabral, M.J. Gonçalves, C. Cavaleiro M.T. Cruz, M. Paoli, F. Tomi, T. Efferth and L. Salgueiro, Ziziphora tenuior L. essential oil from Dana Biosphere Reserve (Southern Jordan); chemica characterization and assessment of biological activities, Journal c Ethnopharmacology, http://dx.doi.org/10.1016/j.jep.2016.10.076

This is a PDF file of an unedited manuscript that has been accepted fo publication. As a service to our customers we are providing this early version o the manuscript. The manuscript will undergo copyediting, typesetting, an review of the resulting galley proof before it is published in its final citable form Please note that during the production process errors may be discovered whic could affect the content, and all legal disclaimers that apply to the journal pertain 


\section{Ziziphora tenuior L. essential oil from Dana Biosphere Reserve (Southern Jordan); chemical characterization and assessment of biological activities}

Abu-Darwish $\mathrm{MS}^{1,21}$, Cabral $\mathrm{C}^{31^{*}}$, Gonçalves $\mathrm{MJ}^{3}$, Cavaleiro $\mathrm{C}^{3}$, Cruz $\mathrm{MT}^{3}$, Paoli $\mathrm{M}^{4}$,Tomi F${ }^{4}$, Efferth $\mathrm{T}^{5}$, Salgueiro $\mathrm{L}^{3}$

${ }^{1}$ Department of Basic and Applied Sciences, Shouback University College/ Maan College, AlBalqa Applied University, Al-Salt 19117, Jordan

${ }^{2}$ National Center for Natural Products Research, School of Pharmacy, University of Mississippi, MS 38677, USA

${ }^{3}$ CNC.IBILI/ Faculty of Pharmacy, University of Coimbra, Azinhaga de S. Comba 3000-354 Coimbra, Portugal

${ }^{4}$ Université de Corse-CNRS, UMR 6134 SPE, Equipe Chimie et Biomasse, 20000 Ajaccio, France

${ }^{5}$ Department of Pharmaceutical Biology, Institute of Pharmacy and Biochemistry, Johannes Gutenberg University, Staudinger Weg 5, 55128 Mainz, Germany

*Corresponding author: Laboratório de Farmacognosia, Faculdade de Farmácia da Universidade de Coimbra, Pólo das Ciências da Saúde, Azinhaga de Santa Comba, 3000-548 Coimbra, Portugal. Tel.: +00351239488400; fax:+00351 239488503.celiacabral@ff.uc.pt

\section{Abstract \\ Ethnopharmacologic relevance:}

Ziziphora tenuior L. (Lamiaceae) is a medicinal plant in Jordan, which is included in various antimicrobial, antiseptic, expectorant and wound healing preparations. It is used for the treatment

\footnotetext{
${ }^{1}$ These authors contributed equally for this work
} 
of cough, stomach ache, dysentery, fever, uterus infection, gut inflammation and painful menstruation.

\section{Aim of the study:}

The aim of this study was to assess, for the first time, the chemical composition of the essential oil of Z. tenuior originated from southern Jordan and its antifungal effects against several yeasts. Concomitantly, the mechanisms behind the anti-fungal activity against Candida albicans were also disclosed. Since the Z. tenuior traditional uses are related with inflammatory-associated conditions, the putative anti-inflammatory activity of the oil was also unveiled. Importantly, the potential toxicity of pharmacologically active concentrations was screened in different types of mammalian cells.

\section{Materials and methods:}

Z. tenuior essential oil, isolated by hydrodistillation, was analyzed by gas chromatography, gas chromatography-mass spectrometry and ${ }^{13} \mathrm{C}$ nuclear magnetic resonance spectroscopy. Antifungal activity was evaluated against yeasts, dermatophytes and Aspergillus strains. Germ tube inhibition and biofilm formation assays were evaluated using C. albicans. Assessment of cell viability was made by the MTT assay using different types of mammalian cells, including hepatocytes, keratinocytes and macrophages. The in vitro anti-inflammatory potential of the oil was evaluated by measuring nitric oxide production using lipopolysaccharide-stimulated mouse macrophages.

\section{Results:}

Oxygen-containing monoterpenes are the main oil compounds: pulegone (46.8\%), $p$-menth-3-en8-ol $(12.5 \%)$, isomenthone $(6.6 \%)$ and 8 -hydroxymenthone $(6.2 \%)$. The highest antifungal activity was against Cryptococcus neoformans, with a MIC value of $0.16 \mu \mathrm{L} / \mathrm{mL}$. The oil revealed an important inhibitory effect on germ tube formation with a filamentation inhibition rate higher than $80 \%$ at $0.16 \mu \mathrm{L} / \mathrm{mL}$. The amount of the attached biomass was reduced. Importantly, concentrations devoid of toxicity on several mammalian cell types still displayed anti-inflammatory activity $(0.16$ and $0.32 \mu \mathrm{L} / \mathrm{mL})$.

\section{Conclusions:}

These findings add significant information to the pharmacological activity of Z. tenuior, thus justifying and reinforcing the use of this plant in traditional medicine. Additionally, the 
antifungal and anti-inflammatory potential of the oil at non-toxic concentrations, opens new avenues for its further exploitation, for instance in health-care product development.

\section{Abbreviations:}

GC, gas chromatography; LPS, lipopolysaccharide; MIC, minimal inhibitory concentration; NO, nitric oxide; MLC, minimal lethal concentration; MS, mass spectrometry; NMR, nuclear magnetic resonance; TLR, toll-like receptor

Keywords: Ziziphora tenuior; essential oil; chemical composition; antifungal activity; antiinflammatory activity; cytotoxicity

\section{Introduction}

Ziziphora tenuior L. (Arabic: Zizfran), is one of four species belonging to the genus Ziziphora (Lamiaceae). It is distributed in steppes, Al-Nagab desert, lower Jordan valley, Araba valley, Amman, Madaba and Edom (Zohary and Feinbrun, 1978; Al- Baba et al., 2015) and in the southern parts of Jordan mainly in Al-Shoubak, Tafila, Dana and Petra (Al-Rawashdeh, 2011; Oran 2013; Taifour and El-Oqlah, 2014). Additionally, this plant grows in Mediterranean and Iran-Turonian zones, including some parts of Iran, Turkey, Afghanistan, Iraq and Azerbaijan (Verdian-Rivi, 2008; Al-Rawashdeh, 2011; Darbandi et al., 2013; Taifour and El-Oqlah, 2014). Z. tenuior is also distributed in Russia, Turkmenistan, Afghanistan, Pakistan, Caucasus and Siberia (Rechinger, 1982).

Z. tenuior is an aromatic herbaceous plant used for many traditional preparations against various diseases. In Jordan, it is traditionally used as common teapot herb (Al-Rawashdeh, 2011; AlBaba et al., 2015). Interestingly, in other Arabic regions, Turkey and Iran, Z. tenuior plays an important role in traditional medicine. In Iranian folk medicine, it is used to treat fever, dysentery and uterus infections (Talebi et al., 2012), gut inflammation and cough (Safa et al., 2012), bladder stone and painful menstruation (Naghibi et al., 2005). In the folk medicine of the Kalamoon Mountains area in Syria, it is used against cough, stomachache and dysentery (Dakah et al., 2015). In Turkish folk medicine, Ziziphora species have been used as infusion for various purposes such as antimicrobial, antiseptic, sedative and carminative effects as well as to treat 
stomach ache and wound healing (Kilic and Bagci, 2013; Celik et al., 2016). Further emphasizing its ethnopharmacological relevance, the essential oils of Ziziphora species are used for treating edema, insomnia, lung abscess, tracheitis, hemorrhoids and hypertension (Senejouxa et al., 2010).

Several antimicrobial properties have also been ascribed to the extract. For instance, the methanolic extract of the $Z$. tenuior exhibited significant antimicrobial effects against Morganella morganii and Candida albicans (Bazzaz et. al., 2003).

Numerous other important immunological activities have been assigned to Z. tenuior. Azadmehr et al. (2014) showed that Z. tenuior ethanolic extract (80\% ethanol) modulated the immune response by induction of CD40 expression in dendritic cells (DCs) and cytokine production, whereas it inhibited the T-cell stimulating activity of DCs at high concentrations. Furthermore, the water extract of $Z$. tenuior increased macrophage activity $(\mathrm{p}<0.05)$ (Naeini et al., 2010) and significantly induced the generation of reactive oxygen species, revealing strong fungicidal activities in treated macrophages at concentrations of 10 and $20 \mathrm{mg} / \mathrm{mL}(\mathrm{p}<0.05)$ (Naeini et al., 2010).

Several biological activities have also been attributed to Z. tenuior. For instance, the essential oil of Z. tenuior originated from Turkey showed antimicrobial activity against some Gram-positive and Gram-negative bacteria (Sarac and Ugur, 2009). Additionally, Celik et al. (2016) evaluated the anti-biofilm and antimicrobial properties of $Z$. tenuior L. essential oil against multidrugresistant Acinetobacter baumannii, where minimal inhibition concentration (MIC) values of 0.6$1.25 \mu \mathrm{L} / \mathrm{mL}$ and minimal bactericidal concentration values of $2.5-5.0 \mu \mathrm{L} / \mathrm{mL}$ were found. Furthermore, minimal biofilm inhibition concentration values of $0.3-1.25 \mu \mathrm{L} / \mathrm{mL}$ and minimal biofilm eradication concentration values of $5-10 \mu \mathrm{L} / \mathrm{mL}$ were observed.

Concerning the chemical composition of the essential oil, pulegone, isomenthone, thymol, menthone and piperitone were the major constituents in the oil of Z. tenuior originated from Turkey (Sezik et al., 1991), while pulegone (30.00\%) and 1,8-cineole (9.65\%) were identified as major components in Z. tenuior originated from Adiyaman/Turkey (Kilic and Bagci, 2013). Pulegone (71.2 to $85.3 \%)$, limonene (0.51 to $7.8 \%)$, thymol (1.0 to $4.3 \%)$, and menthone (0.1 to $3.7 \%$ ) were the major components in the oils from various natural habitats in the alpine regions, Kerman province, and Iran (Pirbalouti et al., 2013). Essential oil of Z. tenuior collected from the 
northern part of Shiraz, Iran contained p-mentha-3-en-8-ol (54.0\%) and pulegone (38.5\%) but not piperitenone (Darbandi et al., 2013) compared to the oil of other Ziziphora species from Turkey. These data indicate that the yield and composition of essential oil of Z. tenuior may be affected by genetic and ecological factors, including plant genetics, environmental conditions, and geographic origin such as climate precipitation, altitude, temperature, plant competition and nitrogen concentration in the soil (Pirbalouti et al., 2013; Maral et al., 2015).

We previously evaluated the content of heavy metals $(\mathrm{Fe}, \mathrm{Mn}, \mathrm{Zn}$ ) in aerial parts of $Z$. tenuior originated from Shoubak (Ofir and Abu-Darwish, 2012). Apart from this study, there is currently no other report available concerning the chemical composition as well as the antifungal and antiinflammatory properties of $Z$. tenuior originated from Jordan. Taking into account that $Z$. tenuior is one of the medicinal plants of Jordan, which are counted as important elements of folk medicine for treating certain health disorders, it is of utmost importance to validate its traditional use by modern pharmacological research. In order to fill this gap, the aim of this study was to assess, for the first time, the chemical composition of the essential oil of Z. tenuior originated from southern Jordan and its antifungal effect against several yeasts, dermatophytes and Aspergillus strains. Concomitantly, the mechanisms behind the anti-fungal activity against Candida albicans were also disclosed with a special focus on the inhibition of germ tube formation and on preformed biofilms. Additionally, and since most chronic illnesses, including cancer, diabetes, and cardiovascular disease, are mediated through chronic inflammation, the anti-inflammatory activity of the oil was also unveiled. Importantly, the potential toxicity of bioactive concentrations was screened in different types of mammalian cells, including hepatocytes, keratinocytes and macrophages.

\section{Materials and methods}

\subsection{Isolation of essential oil}

Aerial parts of Ziziphora tenuior were collected in various parts of the Dana Biosphere Reserve (DBR) near Tafilah in southern Jordan, latitude ( $\left.30^{\circ} 40^{\prime} 33 \mathrm{~N}\right)$, longitude $\left(35^{\circ} 36^{\prime} 39 \mathrm{E}\right)$, altitude $(1543 \mathrm{~m})$, during spring in 2015 , in order to obtain a collective sample representative of the region. In Jordan, it is one of the endangered medicinal plants that is included into the red list (Taifour and El-Oqlah, 2014). The investigations of the present paper have been done with 
official permission of the Royal Botanical Garden, Jordan with letter from July $50^{\text {th }} 2015$. The plant sample was identified by Mr. Hatem Taifour, head botanist at Royal Botanic Garden, Jordan. A voucher specimen was deposited in the Herbarium of Shoubak University College, AlBalqa Applied University, Jordan under the registration number 00014- Zt-DAsh-2015. The collected plant material was dried at room temperature and crushed into small pieces with a hammer mill.

Essential oil was isolated by hydro-distillation for $3 \mathrm{~h}$ using a Clevenger-type apparatus (Normax, Lisboa, Portugal), according to the procedure described in the European Pharmacopoeia (Council of Europe, 1997). The oil obtained after extraction was dried over anhydrous sodium sulphate and kept under $4^{\circ} \mathrm{C}$ until analyzed and tested.

\subsection{Chemical composition}

\subsubsection{Gas chromatography (GC) analysis}

Analyses were performed on a Clarus 500 Perkin Elmer (Courtaboeuf, France) chromatograph equipped with flame ionization detectors FID and two fused-silica capillary columns $(50 \mathrm{~m} \times$ $0.22 \mathrm{~mm}$, film thickness $0.25 \mu \mathrm{m}$ ), BP-1 (polydimethyl siloxane) and BP-20 (polyethylene glycol). The oven temperature was programmed from $60-220^{\circ} \mathrm{C}$ at $2{ }^{\circ} \mathrm{C} / \mathrm{min}$ and then held isothermal at $220^{\circ} \mathrm{C}$ for $20 \mathrm{~min}$; injector temperature: $250^{\circ} \mathrm{C}$; detector temperature: $250^{\circ} \mathrm{C}$; carrier gas: helium $(1.0 \mathrm{~mL} / \mathrm{min})$; split: $1 / 60$; injection volume, $0.5 \mu \mathrm{L}$. Retention indices (RI) were determined relative to the retention times of a series of $n$-alkanes with linear interpolation (« Target Compounds » software from Perkin Elmer).

\subsubsection{Gas chromatography-mass spectrometry (GC-MS) analysis}

The essential oils were analyzed with a Perkin-Elmer (Courtaboeuf, France) TurboMass detector (quadrupole), directly coupled to a Perkin-Elmer Autosystem equipped with two fused silica capillary columns $(50 \mathrm{~m} \times 0.22 \mathrm{~mm} \times 0.25 \mu \mathrm{m}$ film thickness), BP-1 (polydimethyl siloxane) and BP-20 (polyethylene glycol). Carrier gas was helium at $0.8 \mathrm{~mL} / \mathrm{min}$, split $1 / 75$. Further conditions were: injection volume, $0.5 \mu \mathrm{L}$; injector temperature, $250^{\circ} \mathrm{C}$; oven temperature programmed from $60^{\circ} \mathrm{C}$ to $220^{\circ} \mathrm{C}$ at $2^{\circ} \mathrm{C} / \mathrm{min}$ and then held isothermal $(20 \mathrm{~min}$ ); ion source temperature, $250^{\circ} \mathrm{C}$; energy ionization, $70 \mathrm{eV}$. The electron ionization mass spectra were acquired over a mass range of 40-400 Da. 


\subsection{3 ${ }^{13}$ C NMR analysis}

All nuclear magnetic resonance (NMR) spectra were recorded on a Bruker AVANCE 400 (Wissembourg, France) (400.132 MHz for ${ }^{1} \mathrm{H}$ and $100.623 \mathrm{MHz}$ for ${ }^{13} \mathrm{C}$ ) equipped with a $5 \mathrm{~mm}$ probe, in deuterated chloroform $\left(\mathrm{CDCl}_{3}\right)$, with all shifts referred to internal tetramethylsilane (TMS). ${ }^{13} \mathrm{C}$ NMR spectra were recorded with the following parameters: pulse width, $4 \mu$ s (flip angle $45^{\circ}$ ); acquisition time, $2.7 \mathrm{~s}$ for $128 \mathrm{~K}$ data table with a spectral width of $24000 \mathrm{~Hz}$ (240 ppm); digital resolution, $0.183 \mathrm{~Hz} /$ pt. The number of accumulated scans was 3000 (around 50 $\mathrm{mg}$ of the oil sample in $0.5 \mathrm{~mL}$ of $\mathrm{CDCl}_{3}$ ).

\subsubsection{Identification of Individual Components}

Identification of the individual components was based: (i) on comparison of their GC retention indices (RIs) on apolar and polar columns, determined relative to the retention times of a series of $n$-alkanes with linear interpolation ('Target Compounds' software of Perkin-Elmer), with those of authentic compounds, or literature data, (ii) on a computer search using digital libraries of mass spectral data (National Institute of Standards and Technology, 1999; Konig et al., 2001) and/or literature data (Joulain and Konig, 1998; Adams, 2007) and (iii) by ${ }^{13} \mathrm{C} N M R$ spectroscopy, following a computerized method developed in our laboratory (Tomi et al., 1995; Tomi and Casanova, 2006; Bighelli and Casanova, 2010), using a tailor-made software, by comparison of the chemical shift values of the signals in the essential oil spectrum with those of reference compounds compiled in a laboratory-built library. This method allowed the identification of individual components of the essential oil at contents as low as $0.3-0.4 \%$. A few compounds have been identified by comparison with literature data.

\subsection{Antifungal activity}

\subsubsection{Fungal strains}

The following clinical isolates and collection strains of Candida, Cryptococcus neoformans, Aspergillus, and dermatophyte species were used: two Candida clinical strains (Candida guilliermondii MAT23 and C. krusei H9), isolated from recurrent cases of vulvovaginal candidiasis, and three ATCC type strains (C. albicans ATCC 10231, C. tropicalis ATCC 13803, and C. parapsilosis ATCC 90018); Cryptococcus neoformans type strain from the Colección 
Espanõla de Cultivos Tipo (C. neoformans CECT 1078), one Aspergillus clinical strain isolated from bronchial secretions (A. flavus F44), two ATCC Aspergillus type strains (Aspergillus niger ATCC 16404 and Aspergillus fumigatus ATCC 46645), and three dermatophyte clinical strains isolated from nails and skin (Epidermophyton floccosum FF9, Microsporum canis FF1, and Trichophyton mentagrophytes FF7), as well as four dermatophyte type strains (M. gypseum CECT 2908, T. mentagrophytes var. interdigitale CECT 2958, T. rubrum CECT 2794, and T. verrucosum CECT 2992). The clinical isolates were identified by standard microbiological methods and stored on Sabouraud dextrose broth (Becton-Dickinson) with $20 \%$ glycerol at $-80^{\circ} \mathrm{C}$. Prior to antifungal susceptibility testing, each isolate was inoculated on Sabouraud dextrose agar (SDA; Becton-Dickinson) to ensure optimal growth and purity.

The fungal isolates were identified by standard microbiological methods and stored on Sabouraud broth with glycerol at $-70^{\circ} \mathrm{C}$.

\subsubsection{Antifungal activity methods}

Broth macrodilution methods based on the Clinical and Laboratory Standards Institute (CLSI) reference protocols M27-A3 (CLSI, 2008a) and M38-A2 (CLSI, 2008b) for yeasts and filamentous fungi, respectively, were used to determine MIC and minimally lethal concentration (MLC) of the essential oils. The serial doubling dilution of the essential oil was prepared in dimethyl sulfoxide (DMSO), with concentrations ranging from 0.08 to $10 \mu \mathrm{L} / \mathrm{mL}$. The final concentration of DMSO never exceeded $2 \%$. Recent cultures of each strain were used to prepare the cell suspensions and adjusted to $1-2 \times 10^{3}$ cells per $\mathrm{mL}$ for yeasts, and $1-2 \times 10^{4}$ cells per $\mathrm{mL}$ for filamentous fungi. The concentration of the cells was confirmed by viable count on Sabouraud agar. The test tubes were incubated aerobically at $35^{\circ} \mathrm{C}$ for $48 \mathrm{~h}$ or $72 \mathrm{~h}$ (Candida spp./Cryptococcus neoformans/Aspergillus) and at $30^{\circ} \mathrm{C}$ for 7 days (dermatophytes) and MICs were determined. To evaluate MLCs, aliquots $(20 \mu \mathrm{L})$ of broth were taken from each negative tube after MIC measurement and cultured in Sabouraud dextrose agar plates. Plates were then incubated at $35^{\circ} \mathrm{C}$ for $48 \mathrm{~h}$ (Candida spp./Aspergillus spp.), $72 \mathrm{~h}$ for Cryptococcus neoformans, or $30^{\circ} \mathrm{C}$ for 7 days (dermatophytes). In addition, two reference antifungal compounds, amphotericin B (Fluka) and fluconazole (Pfizer), were used to monitor the sensitivity of the tested microorganisms. All tests were performed in RPMI medium. For each strain tested, both growth conditions and sterility of the medium were controlled in two control tubes. The 
innocuity of DMSO was also proven at the highest tested concentration. All experiments were performed in triplicate and repeated, if the results differed.

\subsubsection{Germ tube inhibition assay}

In order to determine the effect of the volatile oil on the yeast-mycelium transition, cell suspensions from overnight SDA of C. albicans strains ATCC 10231 cultures were prepared in NYP medium (N-acetylglucosamine [Sigma; 10-3mol/L], Yeast Nitrogen Base [Difco; 3.35

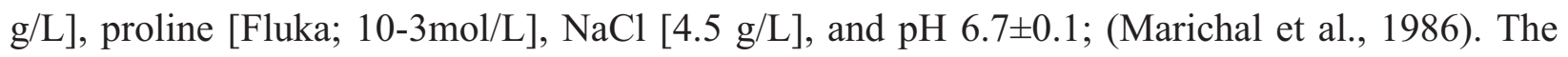
suspensions were adjusted to obtain a density of yeast cell suspensions at $1.0 \pm 0.2 \times 10^{6} \mathrm{CFU} / \mathrm{mL}$ and distributed into glass test tubes in a volume of $990 \mu \mathrm{L}$. Each dilution of essential oil was added into the cell suspension tubes, in $10 \mu \mathrm{L}$ volumes, to obtain appropriate sub-inhibitory concentration. After incubation at $37^{\circ} \mathrm{C}$ without agitation for $3 \mathrm{~h}$, the treated and untreated yeast cells were counted for germ tube formation under light microscope and the percentage of germinating cells was calculated. The formation of germ tube was considered positive, if the germinating tube was at least as long as the diameter of the blastospore. DMSO at a maximal concentration of $1 \%(\mathrm{v} / \mathrm{v})$ was used as control.

\subsubsection{Biofilms formation}

C. albicans biofilms were formed as described by Taweechaisupapong et al. (2010) with slight modifications. Briefly, yeast cells were cultured in Yeast Peptona Dextrose broth (YPD) overnight at $37^{\circ} \mathrm{C}$, washed with PBS and re-suspended in RPMI-1640 $\left(1 \times 10^{6}\right.$ cells $\left./ \mathrm{ml}\right)$. Biofilms were formed on commercially available pre-sterilized polystyrene flat-bottom 96-well microtiter plates by pipetting standardized cell suspensions $\left(100 \mu \mathrm{L}\right.$ of $10^{6}$ cells $\left./ \mathrm{mL}\right)$ into selected wells of the microtiter plate and further incubated at $37^{\circ} \mathrm{C}$ for $24 \mathrm{~h}$. After biofilm formation, the medium was aspirated, and non-adherent cells were removed by thorough washing of the biofilms for three times in sterile PBS. Residual PBS was removed by blotting with paper towels before addition of the essential oil. The oil was then added to the biofilms in serially double-diluted concentrations in DMSO (0.32 to $2.5 \mu \mathrm{L} / \mathrm{mL})$ and incubated for $24 \mathrm{~h}$ at $37^{\circ} \mathrm{C}$. A series of essential oil-free wells were also included: DMSO at a maximal concentration of $1 \%(\mathrm{v} / \mathrm{v})$ (control) and biofilm-free wells. The effect of the oil on pre-biofilm growth was determined as 
reported by Raut et al. (2014) with the XTT/Menadione metabolic assay as well as the crystal violet assay.

\subsubsection{Biofilms quantification}

\subsubsection{XTT assay}

Biofilm growth was quantified using the XTT metabolic assay. The XTT solution was prepared by mixing $1 \mathrm{mg} / \mathrm{mL}$ XTT salt (SIGMA) in PBS and stored at $-70^{\circ} \mathrm{C}$. Prior to use, menadione (Sigma) solution was prepared in acetone and added to XTT to a final concentration of $4 \mu \mathrm{M}$. The wells containing biofilms were washed with PBS to remove non-adhered cells and incubated with $100 \mu \mathrm{L}$ of XTT-menadione solution in the dark, at $37^{\circ} \mathrm{C}$ for $2 \mathrm{~h}$. The color formation by the water-soluble formazan product was measured at $450 \mathrm{~nm}$ using a microplate reader (Thermo Scientific ${ }^{\mathrm{TM}}$ Multiskan ${ }^{\mathrm{TM}} \mathrm{FC}$ ) and indicated the metabolic activity relatively to biofilm growth.

\subsubsection{Cristal violet assay}

Biofilm cells were fixed with 99\% methyl alcohol for 15 min. Supernatants were removed, and wells were air-dried. One hundred microliters of $0.02 \%$ crystal violet were added to each well and allowed to stand for $15 \mathrm{~min}$ for staining of the biofilm. Excessive crystal violet was removed by washing the wells 2-3 times with sterile distilled water. Absorbed stain was released by addition of $150 \mu \mathrm{L}$ of $33 \%$ of acetic acid and transferred to the new wells. Absorbance measurement was read at $620 \mathrm{~nm}$ using a microplate reader. The percentage of biofilm mass was calculated by comparing the absorbance measurement of treatment with that of the control biofilm.

\subsection{Measurement of anti-inflammatory activity}

\subsubsection{Cell culture and materials}

The macrophage cell line (Raw 264.7), obtained from the American Type Culture Collection (TIB-71) was kindly supplied by Dr. Otília Vieira (Center for Neuroscience and Cell Biology, University of Coimbra, Portugal). Cells were grown in Dulbecco's Modified Eagle Medium (DMEM) supplemented with 10\% (v/v) non-inactivated fetal bovine serum, $3.02 \mathrm{~g} / \mathrm{L}$ sodium 
bicarbonate, $100 \mu \mathrm{g} / \mathrm{mL}$ streptomycin and $100 \mathrm{U} / \mathrm{mL}$ penicillin at 37 in a humidified atmosphere of $95 \%$ air and $5 \% \mathrm{CO}_{2}$.

\subsubsection{Nitric oxide (NO) measurement}

The anti-inflammatory potential of the essential oil of $Z$. tenuior was evaluated in the macrophage cell line (RAW 264.7). The cells $\left(0.6 \times 10^{6}\right.$ cells/well) were cultured in 48 -well microplates, in a final volume of $600 \mu \mathrm{L}$ and allowed to stabilize for $12 \mathrm{~h}$. Following this period, cells were either maintained in culture medium (control) or pre-incubated with different concentrations of the essential oil or its main compounds for $1 \mathrm{~h}$, and later activated with LPS (1 $\mu \mathrm{g} / \mathrm{mL}$ ) for $24 \mathrm{~h}$. The production of NO was measured by the accumulation of nitrites in the culture supernatants, by the colorimetric reaction with the Griess reagent (Cruz et al., 2001; Green et al., 1982). Briefly, $170 \mu \mathrm{L}$ of medium were diluted with equal volumes of the Griess reagent $[0.1 \%(\mathrm{w} / \mathrm{v}) \quad \mathrm{N}-(1$-naphthyl) ethylenediamine dihydrochloride and $1 \% \quad(\mathrm{w} / \mathrm{v})$ sulphanilamide containing 5\% (w/v) $\left.\mathrm{H}_{3} \mathrm{PO}_{4}(\mathrm{v} / \mathrm{v})\right]$ and maintained during $30 \mathrm{~min}$, in the dark. The absorbance at $550 \mathrm{~nm}$ was measured in an automated plate reader. The results were expressed as the percentage of nitrite production by cells cultured with LPS.

\subsection{In vitro cytotoxicity evaluation}

\subsubsection{Cell culture and materials}

The human keratinocytes cell line (HaCaT), obtained from the German Cancer Research Center (DKFZ, Heidelberg), was kindly supplied by Dr. Eugenia Carvalho (Centre for Neuroscience and Cell Biology, University of Coimbra, Portugal). Keratinocytes were cultured in Dulbecco's Modified Eagle Medium (high glucose) supplemented with 10\% (v/v) inactivated fetal bovine serum, $3.02 \mathrm{~g} / \mathrm{L}$ sodium bicarbonate, $100 \mu \mathrm{g} / \mathrm{mL}$ streptomycin and $100 \mathrm{U} / \mathrm{ml}$ penicillin, at $37^{\circ} \mathrm{C}$ in a humidified atmosphere of $95 \%$ air and $5 \% \mathrm{CO}_{2}$.

The human hepatocyte cell line (HepG2) was purchased from ATCC (number: 77400) and kindly provided by Dr. Conceição Pedroso Lima. Hepatocytes were cultured in Dulbecco's Modified Eagle Medium (high glucose) supplemented with 10\% (v/v) inactivated fetal bovine serum, with $1.5 \mathrm{~g} / \mathrm{L}$ sodium bicarbonate, $100 \mathrm{U} / \mathrm{mL}$ penicillin, $100 \mu \mathrm{g} / \mathrm{mL}$ streptomycin and kept at $37^{\circ} \mathrm{C}$ in a humidified atmosphere of $95 \%$ air and $5 \% \mathrm{CO}_{2}$.

The method for culturing the cell line of macrophages (RAW 264.7) is described above. 


\subsubsection{MTT assay for cell viability}

Cell viability was assessed for the essential oil of $Z$. tenuior in different mammalian cell types, namely macrophages (Raw 264.7), keratinocytes (HaCaT) and hepatocytes (HepG2).

Evaluation of cell viability was performed by a colorimetric assay using the 3-(4,5dimethylthiazol-2-yl)-2,5-diphenyltetrazolium bromide (MTT) reduction colorimetric assay, as previously reported (Mosmann, 1983). Macrophages, keratinocytes and hepatocytes were cultured at densities of $0.6 \times 10^{6} ; 0.2 \times 10^{6} ; 0.2 \times 10^{6}$ cells/well, respectively, in 48-well microplates in a final volume of $600 \mu \mathrm{L}$ for $12 \mathrm{~h}$ and were further treated with different concentrations of the oil ( 0.16 to $1.25 \mu \mathrm{L} / \mathrm{mL})$.

After $24 \mathrm{~h}, 60 \mu \mathrm{L}$ of a MTT solution $(5 \mathrm{mg} / \mathrm{mL}$ in PBS) were added per well to keratinocytes and hepatocytes and $43 \mu \mathrm{L}$ of MTT solution per well to macrophages. Cells were further incubated at $37^{\circ} \mathrm{C}$ in a humidified atmosphere of $95 \%$ air and $5 \% \mathrm{CO}_{2}$ for $30 \mathrm{~min}$ (keratinocytes) / or $1 \mathrm{~h}$ (hepatocytes and macrophages). After this time period of incubation with MTT, the supernatants were discarded and $300 \mu \mathrm{L}$ of acidic isopropanol $(0.04 \mathrm{~N} \mathrm{HCl}$ in isopropanol) were added to each well. Quantification of formazan crystals was performed using an ELISA microplate reader at $570 \mathrm{~nm}$ with a reference wavelength of $620 \mathrm{~nm}$. The results were expressed as the percentage of MTT reduction relatively to control cells.

\subsection{Data analysis}

All the experiments were performed in duplicate, being the results expressed as mean $\pm \mathrm{SEM}$ of three independent experiments. Statistical analyses were performed using one-way ANOVA with a Dunnett's multiple comparison test. The statistical tests were applied using GraphPad Prism, version 6.00 (GraphPad Software, San Diego, CA, USA).

\section{Results and discussion}

\subsection{Essential oil composition}

The essential oil of Jordanian Ziziphora tenuior was obtained with a yield of $0.72 \%$, which is comparable to previously published yields obtained from this species growing in other countries. The oil yield from the aerial parts of Z. tenuior from alpine regions, Kerman province, Iran, 
ranged from 0.61 to $0.75 \mathrm{~mL} / 100 \mathrm{~g}$ dry plants (Pirbalouti et al., 2013), and a range of $0.2 \%$ to $2.3 \%$ oils was measured in flowering branches of Z. tenuior grown in Isfahan, Iran (Batooli et al., 2012). This variation in essential oil yield is related to many different factors. For instance, environmental conditions, geographic origin and climate can affect the yield and the content of Z. tenuior essential oil (Pirbalouti et al., 2013). The levels of altitudes also influenced the contents of essential oils of Ziziphora. The highest essential oil yield was obtained from plants growing at $908 \mathrm{~m}$ altitude above sea level in comparison with those growing at $1286 \mathrm{~m}$ (Maral et al., 2015).

The essential oil was analyzed by GC(RI), GC-MS and ${ }^{13} \mathrm{C}$ NMR. In total, 36 compounds were identified accounting for $91.0 \%$ of the entire composition (Table 1).

Table 1. Composition of Ziziphora tenuior essential oil from Jordan

\begin{tabular}{|c|c|c|c|c|c|}
\hline & Components & $\mathrm{RI}_{\mathrm{a}}$ & $\mathrm{RI}_{\mathrm{p}}{ }^{\mathrm{c}}$ & $\%$ & Identification \\
\hline 1 & 3-methylcyclohexanone & 920 & 1340 & 0.3 & RI, MS \\
\hline 2 & $\alpha$-pinene & 930 & 1016 & 0.2 & RI, MS \\
\hline 3 & camphene & 943 & 1065 & $\operatorname{tr}$ & RI, MS \\
\hline 4 & oct-1-en-3-ol & 960 & 1456 & $\operatorname{tr}$ & RI, MS \\
\hline 5 & sabinene & 964 & 1122 & 0.1 & RI, MS \\
\hline 6 & $\beta$-pinene & 969 & 1111 & 0.3 & RI, MS \\
\hline 7 & octanal & 983 & 1282 & $\operatorname{tr}$ & RI, MS \\
\hline 8 & $p$-cymene & 1011 & 1270 & 0.1 & RI, MS \\
\hline 9 & limonene* & 1020 & 1201 & 3.2 & $\mathrm{RI}, \mathrm{MS},{ }^{13} \mathrm{C}$ NMR \\
\hline 10 & 1,8-cineole* & 1020 & 1210 & 1.2 & $\mathrm{RI}, \mathrm{MS},{ }^{13} \mathrm{C}$ NMR \\
\hline 11 & $p$-mentha-3,8-diene & 1056 & 1264 & 0.2 & RI, MS \\
\hline 12 & $\alpha$-thujone & 1085 & 1422 & 0.3 & RI, MS \\
\hline 12 & $\beta$-thujone & 1096 & 1441 & 0.3 & RI, MS \\
\hline 14 & trans-p-mentha-2,8-dien-1-ol & 1102 & 1625 & 0.1 & RI, MS \\
\hline 15 & $c i s$ - $p$-mentha-2,8-dien-1-ol & 1115 & 1657 & 0.1 & RI, MS \\
\hline 16 & camphor & 1120 & 1516 & 0.7 & $\mathrm{RI}, \mathrm{MS},{ }^{13} \mathrm{C}$ NMR \\
\hline 17 & $p$-menth-3-en-8-ol & 1132 & 1605 & 12.5 & $\mathrm{RI}, \mathrm{MS},{ }^{13} \mathrm{C}$ NMR \\
\hline 18 & isomenthone & 1141 & 1491 & 6.6 & $\mathrm{RI}, \mathrm{MS},{ }^{13} \mathrm{C} \mathrm{NMR}$ \\
\hline 19 & cis-isopulegone & 1148 & 1572 & 0.4 & RI, MS \\
\hline 20 & trans-isopulegone & 1149 & 1584 & 0.4 & RI, MS \\
\hline 21 & terpinen-4-ol & 1160 & 1599 & 0.2 & RI, MS \\
\hline 22 & isomenthol & 1171 & 1663 & 4.7 & $\mathrm{RI}, \mathrm{MS},{ }^{13} \mathrm{C}$ NMR \\
\hline 23 & trans-carveol & 1197 & 1831 & 0.3 & RI, MS \\
\hline 24 & pulegone & 1214 & 1645 & 46.8 & $\mathrm{RI}, \mathrm{MS},{ }^{13} \mathrm{C} \mathrm{NMR}$ \\
\hline
\end{tabular}




$\begin{array}{lllllc}25 & \text { 8-hydroxymenthone } & 1223 & 1758 & 6.2 & \text { RI, }{ }^{13} \mathrm{C} \text { NMR } \\ 26 & \text { carvone } & 1225 & 1732 & 0.2 & \text { RI, MS } \\ 27 & \text { trans-pulegone oxide } & 1228 & 1813 & 0.9 & \text { RI, MS } \\ 28 & \text { 8-hydroxyisomenthone } & 1255 & 1818 & 0.9 & \text { RI, }{ }^{13} \mathrm{C} \mathrm{NMR} \\ 29 & \text { cis-pulegone oxide } & 1265 & 1909 & 0.6 & \mathrm{RI}, \mathrm{MS} \\ 30 & \text { isomenthyl acetate } & 1278 & 1559 & 1.8 & \mathrm{RI}, \mathrm{MS},{ }^{13} \mathrm{C} \text { NMR } \\ 21 & \text { piperitenone } & 1307 & 1917 & 0.6 & \mathrm{RI}, \mathrm{MS} \\ 32 & \text { mintlactone } & 1448 & 2316 & 0.4 & \mathrm{RI}, \mathrm{MS} \\ 33 & \text { spathulenol } & 1567 & 2115 & 0.2 & \mathrm{RI}, \mathrm{MS} \\ 34 & \text { caryophyllene oxide } & 1578 & 1975 & 0.1 & \mathrm{RI}, \mathrm{MS} \\ 35 & \text { viridiflorol } & 1591 & 2076 & \operatorname{tr} & \mathrm{RI}, \mathrm{MS} \\ 36 & \text { manool } & 2035 & 2644 & 0.1 & \\ \text { Total } & & & & 91.0 & \end{array}$

Order of elution and percentages of individual components are given on apolar column (BP-1) except for the compounds with an asterisk * (polar column BP-20). $\mathrm{RI}_{\mathrm{a}}, \mathrm{RI}_{\mathrm{p}}$ : retention indices calculated on apolar and polar columns respectively. $\operatorname{tr}=$ traces, $<0.05 \%$.

The oil was dominated by C-3 oxygenated $p$-menthane derivatives: pulegone (46.8\%) was by far the most abundant component, followed by $p$-menth-3-en-8-ol (12.5\%), isomenthone (6.6\%), 8hydroxymenthone $(6.2 \%)$ isomenthol $(4.7 \%)$ and isomenthyl acetate $(1.8 \%)$. Other constituents present at appreciable contents were limonene (3.2\%) and 1,8-cineole (1.2\%). Only three oxygenated sesquiterpenes have been identified as minor components: caryophyllene oxide, spathulenol, viridiflorol and the diterpene manool.-The use of NMR spectroscopy assuredly allowed the identification of several isomers bearing the menthane skeleton, which exhibited similar mass spectra.

\subsection{Antifungal activity}

The antifungal activity of the essential oil against human and animal pathogens is presented in Table 2. The highest antifungal activity was observed against Cryptococcus neoformans with a MIC value of $0.16 \mu \mathrm{L} / \mathrm{mL}$. Regarding filamentous fungi, the essential oil has similar activity against dermatophytes and Aspergillus strains with MICs values of 0.64 to $1.25 \mu \mathrm{L} / \mathrm{mL}$ and showed fungicidal effects against Epithermophyton flocosum with MIC and MLC values of 0.64 $\mu \mathrm{L} / \mathrm{mL}$.

Table 2. Antifungal activity (MIC and MLC) of Ziziphora tenuior for yeasts, dermatophytes and Aspergillus strains. 


\begin{tabular}{|c|c|c|c|c|c|c|}
\hline \multirow{2}{*}{ Strains } & \multicolumn{2}{|c|}{ Ziziphora tenuior } & \multicolumn{2}{|c|}{ Fluconazole } & \multicolumn{2}{|c|}{ Amphotericin B } \\
\hline & MIC $^{(\mathrm{a})}$ & MLC $^{(\mathrm{a})}$ & MIC $^{(\mathbf{b})}$ & MLC $^{(\mathbf{b})}$ & MIC $^{(b)}$ & MLC $^{(b)}$ \\
\hline Candida albicans ATCC 10231 & 1.25 & 1.25 & 1 & $>128$ & N.T & N.T \\
\hline Candida tropicalis ATCC 13803 & 1.25 & 1.25 & 4 & $>128$ & N.T & N.T \\
\hline Candida krusei H9 & 1.25 & 1.25 & 64 & $64-128$ & N.T & N.T \\
\hline Candida guillermondii MAT23 & 1.25 & 1.25 & 8 & 8 & N.T & N.T \\
\hline Candida parapsilosis ATCC 90018 & 1.25 & 2.5 & $<1$ & $<1$ & N.T & N.T \\
\hline Cryptococcus neoformans CECT 1078 & 0.16 & 0.64 & 16 & 128 & N.T & N.T \\
\hline Trichophyton mentagrophytes FF7 & 1.25 & 1.25 & $16-32$ & $32-64$ & N.T & N.T \\
\hline $\begin{array}{l}\text { T. mentagrophytes var. interdigitale } \\
\text { CECT } 2958\end{array}$ & 1.254 & 2.5 & 128 & $\geq 128$ & N.T & N.T \\
\hline T. rubrum CECT 2794 & 0.64 & 1.25 & 16 & 64 & N.T & N.T \\
\hline T. verrucosum CECT 2992 & 0.64 & 1.25 & 128 & $>128$ & N.7 & N.T \\
\hline Microsporum canis FF1 & $1.25-0.64$ & 1.25 & 128 & 128 & N.T & N.T \\
\hline M. gypseum CECT 2905 & 1.25 & 1.25 & 128 & $>128$ & N.T & N.T \\
\hline Epidermophyton floccosum FF9 & 0.64 & 0.64 & & 16 & N.T & N.T \\
\hline Aspergillus niger ATCC16404 & 0.64 & 5 & 10.1 & N.T & $1-2$ & 4 \\
\hline A. fumigatus ATCC 46645 & 0.64 & 2.5 & N.T & N.T & 2 & 4 \\
\hline A. flavus F44 & 1.25 & & N.T & N.T & 2 & 8 \\
\hline
\end{tabular}

a MIC and MLC were determined by a macrodilution method and expressed in $\mu \mathrm{L} / \mathrm{mL}(\mathrm{v} / \mathrm{v})$.

b MIC and MLC were determined by a macrodilution method and expressed in $\mu \mathrm{g} / \mathrm{mL}(\mathrm{w} / \mathrm{v})$.

N.T not tested.

Antimicrobial activity of Ziziphora tenuior essential oil was previously reported against strains of Gram-negative and Gram-positive bacteria, C. albicans and Aspergillus (Mahboubi et al., 2012). The authors reported that the essential oil is active against A. flavus and A. niger as well as against $C$. albicans. In our study, we evaluated the effect on other Candida species, $C$. neoformans and dermatophytes.

Although some studies on the antifungal activity of Ziziphora tenuior oil were previously carried out, the mechanism of action underlying this effect remains unknown. Therefore, in the present study, we attempted to elucidate possible modes of action on C. albicans. Two assays were selected, namely the inhibition of germ tube formation and the disruption of preformed biofilms. The essential oil revealed an important inhibitory effect on germ tube formation in C. albicans tested strain at sub-inhibitory concentrations (Figure 1). At a concentration of 1/16 MIC (0.08 $\mu \mathrm{L} / \mathrm{mL}$ ), the inhibition of filamentation was more than $80 \%$ in comparison to untreated control 
cells. The yeast-mycelium transition in C. albicans has been described as important virulence factor in this species, and it seems that filamentation inhibition per se is sufficient to treat disseminated candidiasis (Saville et al., 2006).

The striking difference between MICs and filamentation-inhibiting concentrations suggest that different mechanisms of action may be responsible for these two biological effects.

Figures 2 and 3 represent the effect of the essential oil on preformed C. albicans biofilms. The XTT assay evaluates cell viability by analyzing the formation of a water soluble crystal formed after mitochondrial metabolization, whereas the crystal violet method quantifies the biomass of the biofilm by its staining with the dye. The oil decreased the metabolic activity compared to control at MIC and $2 \times$ MIC values (Fig.2),

Comparable results were also observed for biofilm biomass reduction demonstrating that 2.5 $\mu \mathrm{L} / \mathrm{mL}(2 \times \mathrm{MIC})$ and $1.25 \mu \mathrm{L} / \mathrm{mL}$ (MIC) of the oil were able to interfere with pre-formed biofilms by reducing the amount of the attached biomass.

\subsection{Anti-inflammatory activity}

To explore whether Ziziphora tenuior oil modulates NO production, we used an in vitro inflammation model consisting of macrophages stimulated with the Toll-like receptor (TLR) 4 agonist, LPS. Indeed, upon TLR activation, macrophages produced large NO amounts. This result is comparable to the situation in several inflammatory-related diseases, namely atherosclerosis, obesity, diabetes and neurodegenerative diseases. For this reason, NO represents a well-established marker of inflammation, and inhibition of its production serves as useful strategy to screen compounds with anti-inflammatory potential (Weinberg et al., 2007). The effect of the oil on NO production was analyzed by measuring the nitrites accumulation in the culture medium of LPS-stimulated macrophages. As shown in Figure 4, NO production in macrophages decreased in the presence of the four tested concentrations of the essential oil: $18.57 \pm 0.55(1.25 \mu \mathrm{L} / \mathrm{mL}), 36.45 \pm 0.27(0.64 \mu \mathrm{L} / \mathrm{mL}), 48.74 \pm 1.07(0.32 \mu \mathrm{L} / \mathrm{mL})$ and $78.51 \pm$ $0.29(0.16 \mu \mathrm{L} / \mathrm{mL})$. It is important to emphasize that the essential oil inhibited NO production evoked by LPS at concentrations, which revealed only very low toxicity $(0.64 \mu \mathrm{L} / \mathrm{mL})$ to macrophages (Figure 5). 


\subsection{Evaluation of cell viability}

In a drug discovery perspective, it is important to assess the toxicological profile of compounds at concentrations presenting relevant bioactivity. Therefore, we further tracked the safety of $Z$. tenuior essential oil in three mammalian cell types, namely macrophages, keratinocytes and hepatocytes, using the MTT assay. Figures 5, 6 and 7 demonstrate that the essential oil of $Z$. tenuior showed very low cytotoxicity towards macrophages and hepatocytes at concentrations up to $0.64 \mu \mathrm{L} / \mathrm{mL}$, and keratinocytes at concentrations up to $0.32 \mu \mathrm{L} / \mathrm{mL}$. Therefore, we conclude that $Z$. tenuior essential oil may represent a safe herbal drug with low toxicity at the doses indicated.

\section{Conclusions}

There is currently no literature available concerning the chemical composition as well as the antifungal and anti-inflammatory properties of Ziziphora tenuior L. essential oil from Dana Biosphere Reserve (Southern Jordan), a medicinal plant used in Jordan for treating several disorders. Therefore, we performed a detailed phytochemical investigation on Z. tenuior essential oil and the associated pharmacological properties, especially its mechanism of action and toxicology, in order to validate its ethnomedicinal use.

The chemical analysis revealed that Z. tenuior essential oil was dominated by $\mathrm{C}-3$ oxygenated $p$ menthane derivatives: pulegone (46.8\%), $p$-menth-3-en-8-ol (12.5\%), isomenthone $(6.6 \%), 8$ hydroxymenthone $(6.2 \%)$ isomenthol $(4.7 \%)$ and isomenthyl acetate $(1.8 \%)$. Interesting results were obtained concerning the antifungal activity against Cryptococcus neoformans, dermatophytes and Aspergillus strains. Remarkably, Z. tenuior essential oil significantly inhibited germ tube formation and disrupted preformed biofilms of C. albicans, two important virulence factors in this species. Hence, the oil represents a good candidate for the treatment of candidiasis. Importantly, concentrations devoid of toxicity in several mammalian cell types also displayed anti-inflammatory activity.

These findings add significant information to the pharmacological activity of Z. tenuior, thus justifying and reinforcing the use of this species in traditional medicine and opening new avenues for their further exploitation, for instance in health-care product development.

\section{Acknowledgements}


This research was funded by FCT - Fundação para a Ciência e a Tecnologia, Portugal under the project PEST C/SAU/LA0001/2013-2014 and by the Post-Doc fellowship SFRH/BPD/68481/2010.

\section{References}

Adams, R.P., 2007. Identification of Essential Oil Components by Gas Chromatography/Mass Spectrometry. 4th ed. Allured Publ. Corp., Carol Stream, IL. 2007.

Al-Baba, H., Shibli, R.A., Akash, M., Al-Qudah, T.S., Tahtamouni, R.W., Al- Ruwaiei, H., 2015. Cryopreservation and Genetic Stability Assessment of Threatened Medicinal Plant (Ziziphora tenuior L.) Grown Wild in Jordan. Jordan J. Biol. Sci. 8(4), 247-256.

Al-Rawashdeh, I., 2011. Molecular Taxonomy among Mentha spicata, Mentha longifolia and Ziziphora tenuior Populations using the RAPD Technique. Jordan J. Biol. Sci. 4, 63- 70.

Azadmehr, A., Mosalla, S., Hajiaghaee, R. and Shahnazi, M., 2014. Immunomodulatory effects of Ziziphora tenuior L. extract on the dendritic cells. DARU J. Pharm. Sci. 22(1), 1-6.

Batooli, H., Akhbari, M. and Hosseinizadeh, S.M.J., 2012. Effect of different distillation methods on quantity and quality of essential oil of two Ziziphora L. species. J. Herbal Drugs (An International Journal on Medicinal Herbs) 3(3), 135-146.

Bazzaz, B.S.F., Haririzadeh, G., 2003. Screening of Iranian plants for antimicrobial activity. Pharm. Biol. 41 (8), 573-583.

Bighelli, A., Casanova, J., 2010. The genus Cymbopogon. In Essential Oil-Bearing Grasses, A. Akhila (ed.). CRC Press: Boca Raton, FL, 195.

Celik, C., Tutar, U., Karaman, I., Hepokur, C., Atas, M., 2016. Evaluation of the Antibiofilm and Antimicrobial Properties of Ziziphora tenuior L. Essential Oil Against Multidrug-resistant Acinetobacter baumanni. Int. J. Pharmacol. 12 (1), 28-3.

CLSI - Clinical and Laboratory Standards Institute, 2008a. Reference Method for Broth

Dilution Antifungal Susceptibility Testing of Yeasts. Approved Standard, third ed., M27-A3, Wayne, PA. 
CLSI - Clinical and Laboratory Standards Institute, 2008b. Reference Method for Broth Dilution Antifungal Susceptibility Testing of Filamentous Fungi. Approved Standard, third ed., M38-A2, Wayne, PA.

Council of Europe, 1997. European Pharmacopoeia, third ed. Council of Europe, Strasbourg.

Cruz, M.T., Duarte, C.B., Gonçalo, M., Figueiredo, A., Carvalho, P., Lopes, M.C., 2001.

Granulocyte-macrophage colony-stimulating factor activates the transcription of nuclear factor kappa $\mathrm{B}$ and induces the expression of nitric oxide synthase in a skin dendritic cell line. Immunol. Cell Biol. 79(6), 590-596.

Dakah, A., Suleiman, M., Zaid S., 2015. Genetic Relationship among Wild Medicinal Genotypes of Ziziphora canescens Benth. and Ziziphora tenuior L. and Detection of Genetic Variations Resulted From Tissue Culture, Salinity and pH Media. AJABS 10 (3), 144.156.

Darbandi, T., Honarvar, B., Nobandeganic, M.S., Ardeshir R., 2013, Extraction of Ziziphora tenuior essential oil using supercritical CO2. Eur. J. Exp. Biol. 3(3), 687-695.

Green, L.C., Wagner, D.A., Glogowski, J., Skipper, P.L., Wishnok, J.S., Tannenbaum, S.R., 1982. Analysis of nitrate, nitrite, and [15N] nitrate in biological fluids. Anal. Biochem. 126, $131-138$.

Joulain, D., König, W.A., 1998. The atlas of spectral data of sesquiterpene hydrocarbons, E BVerlag, Hamburg.

Kilic, O., Bagci, E., 2013. Essential Oils of Three Ziziphora L. Taxa from Turkey and Their Chemotaxonomy, Asian J. Chem. 25 (13), 7263-7266.

König, W.A., Hochmuth, D.H., Joulain, D., 2001. Terpenoids and Related Constituents of Essential Oils. Library of MassFinder 2.1. Institute of Organic Chemistry, Hamburg.

Mahboubi, M., Bokaee, S., Dehdashti, H. and Feizabadi, M.M., 2012. Antimicrobial activity of Mentha piperitae, Zhumeria majdae, Ziziphora tenuior oils on ESBLs producing isolates of Klebsiella pneumonia. Biharean Biol. 6, 5-9.

Maral, H., Taghikhani, H., Alpaslan, K.A.Y.A., Kirici, S., 2015. The Effect of Different Levels of Altitutes on Composition and Content of Essential Oils of Ziziphora Clinopodioides in Southern of Turkey. Uluslararası Tarım ve Yaban Hayatı Bilimleri Dergisi 1(1), 1-6.

Mosmann, T., 1983. Rapid colorimetric assay for cellular growth and survival: application to proliferation and cytotoxicity assays. J. Immunol. Methods 65, 55-63. 
Naeini, A., Khosravi, A., Tadjbakhsh, H., Ghazanfari, T., Yaraee, R., Shokri, H., 2010. Evaluation of the immunostimulatory activity of Ziziphora tenuior extracts. Comp. Clin. Path. 19(5), 459-463.

Naghibi, F., Mosaddegh, M., Motamed, S.M., Ghorbani, A., 2005. Labiatae family in folk medicine in Iran: From ethnobotany to pharmacology. Iranian J. Pharmaceutical Res. 2, 63-79.

National Institute of Standards and Technology. 1999. PC Version 1.7 of the NIST/EPA/NIH Mass Spectral Library. Perkin-Elmer Corporation: Norwalk, CT.

Ofir, R., Abu-Darwish, M.S., 2012. Desert Plants as Toxic Metals Bio-Indicators and AS Medicinal Plants, Research Cooperation Conference - Dead Sea, 6-7.12.2012,5-8.

Oran, S., 2014. A list of flowering wild plants in Tafila Province, Jordan. IJBC, 16, 28-40.

Pirbalouti, A.G., Amirkhosravi, A., Bordbar F., Hamed, B., 2013. Diversity in the chemical composition of essential oils of Ziziphora tenuior as a potential source of pulegone. Chemija 24(3), 234-239.

Raut, J.S., Shinde, R.B., Chauhan, N.M., Karuppayil, S.M.J., 2014. Phenylpropanoids of plant origin as inhibitors of biofilm formation by Candida albicans. Microbiol. Biotechnol. 24(9), $1216-1225$.

Rechinger, K.H., 1982. Ziziphora in: Flora Iranica No. 150: 480-493. Akademische Druck Verlagsanstalt Graz, Austria.

Safa, O., A.M. Soltanipoor, S. Rastegar, M. Kazemi and N.K. Dehkordi et al., 2012. An ethnobotanical survey on hormozgan province, Iran. Avicenna J. Phytomed., 3: 64-81.

Sarac, N., Ugur, A., 2009. The in vitro antimicrobial activities of the essential oils of some Lamiaceae species from Turkey. J. Med. Food 12(4), 902-907.

Saville, S.P., Lazzell, A.L., Bryant, A.P., Fretzen, A., Monreal, A., Solberg, E.O., Monteagudo, C., Lopez-Ribot, J.L., Milne, G.T., 2006. Inhibition of filamentation can be used to treat disseminated candidiasis. Antimicrob. Agents Chemother. 50, 3312-3316.

Senejouxa, F., Girarda, C., Kerramb, P., Aisac H. A., Berthelota, A., Bévalota, F., Demougeota C., 2010. Mechanisms of vasorelaxation induced by Ziziphora clinopodioides Lam. (Lamiaceae) extract in rat thoracic aorta. J. Ethnopharmacol. 132(1), 268-273.

Sezik, E., Tümen, G., Baser, K.H.C., 1991, Ziziphora tenuior L., a new source of pulegone, Flav. Fragr. J. 6, 101-103.

Taifour, H., El-Oqlah. A., 2015. Jordan Plant Red List. Vol. 1. Royal Botanic Garden, Jordan. 
Talebi, S.M., Rezakhanlou, A., Isfahani, G.S., 2012. Trichomes plasticity in Ziziphora tenuior L. (Labiatae) in Iran: an ecological review. Ann. Biol. Res. 3(1), 668-672.

Taweechaisupapong S., Singhara S., Lertsatitthanakorn P., Khunkitti W., 2010. Antimicrobial effects of Boesenbergia pandurata and Piper sarmentosum leaf extracts on planktonic cells and biofilm of oral pathogens. Pak. J. Pharm. Sci. 23, 224-231.

Tomi, F., Bradesi, P., Bighelli, A., Casanova. J., 1995. Computer-aided identification of individual components of essential oils using carbon-13 NMR spectroscopy. J. Magn. Reson. Anal. 1, 25-34.

Tomi, F., Casanova, J., 2006. ${ }^{13} \mathrm{C}$ NMR as a tool for identification of individual, components of essential oils from Labiatae. Acta Hortic. 723, 185-192.

Verdian-Rivi, M., 2008. Effect of the Essential Oil Composition and biological activity of Ziziphora clinopodiodes Lam. on the against Anopheles stephensi and Culex pipiens parva from Iran. Saudi J. Biol. Sci. 15 (1), 185-188.

Weinberg, J.B., Fermor, B., Guilak, F., 2007. Nitric oxide synthase and cyclooxygenase interactions in cartilage and meniscus -Relationships to joint physiology, arthritis, and tissue repair, in: Harris, R.E.(Ed.), Inflammation in the Pathogenesis of Chronic Diseases: The COX-2 Controversy, Subcellular Biochemistry Series. Springer, New York, pp. 31-62.

Zohary, M., Feinbrun, N., 1978. Flora Palaestina, The Academy of Sciences and Humanities, Jerusalem.

Figure 1. Influence of sub-inhibitory concentrations of $Z$. tenuior essential oil on germ tube formation of Candida albicans ATCC 10231. Ctrl (control); tested concentrations of the essential oil $(0.08-1.25 \mu \mathrm{L} / \mathrm{mL})$. Results are shown as mean \pm SEM of three independent determinations carried out in duplicate $(* * * * \mathrm{p}<0.0001$, compared to control).

Figure 2. Biofilm viability after treatment with $Z$. tenuior essential oil using the XTT viability assay. Ctrl (control); tested concentrations of the essential oil $(0.32-2.5 \mu \mathrm{L} / \mathrm{mL})$. Results are shown as mean \pm SEM of three independent determinations carried out in duplicate $\left({ }^{* *} \mathrm{p}<0.01\right.$, $* * * \mathrm{p}<0.001, * * * * \mathrm{p}<0.0001$, compared to control). 
Figure 3. Biofilm biomass after treatment with $Z$. tenuior essential oil, using the crystal violet assay. Ctrl (control); tested concentrations of the essential oil $(0.32-2.5 \mu \mathrm{L} / \mathrm{mL})$. Results are shown as mean \pm SEM of at least three independent determinations carried out in duplicate $(* * * \mathrm{p}<0.001, * * * * \mathrm{p}<0.0001$, compared to control).

Figure 4. Effect of essential oil of Z. tenuior on NO production in macrophages (Raw 264.7). LPS (control); tested concentrations of the essential oil (0.16-1.25 $\mu \mathrm{L} / \mathrm{mL})$. Results are expressed as a percentage of the nitrite production by cells cultured in the presence of LPS. Each value represents the mean \pm SEM of three independent experiments performed in duplicate $(* * * \mathrm{p}<0.001, * * * * \mathrm{p}<0.0001$, compared to LPS).

Figure 5. Effect of essential oil of Z. tenuior on macrophages (Raw 264.7) viability by the MTT assay. Ctrl (control); tested concentrations of the essential oil $(0.16-1.25 \mu \mathrm{L} / \mathrm{mL})$. Results are expressed as a percentage of MTT reduction by control cells. Each value represents the mean \pm SEM of three independent experiments performed in duplicate $\left({ }^{*} \mathrm{p}<0.05,{ }^{* *} \mathrm{p}<0.01,{ }^{* * *} \mathrm{p}<0.001\right.$, compared to control).

Figure 6. Effect of essential oil of $Z$. tenuior on keratinocytes (HaCaT) viability by the MTT assay. Ctrl (control); tested concentrations of the essential oil $(0.16-1.25 \mu \mathrm{L} / \mathrm{mL})$. Results are expressed as a percentage of MTT reduction by control cells. Each value represents the mean \pm SEM of three independent experiments performed in duplicate $(* * \mathrm{p}<0.01, * * * \mathrm{p}<0.001$, $* * * * p<0.0001$, compared to control).

Figure 7. Effect of essential oil of Z. tenuior on hepatocytes (HepG2) viability by the MTT assay. Ctrl (control); tested concentrations of the essential oil $(0.16-1.25 \mu \mathrm{L} / \mathrm{mL})$. Results are expressed as a percentage of MTT reduction by control cells. Each value represents the mean \pm SEM of three independent experiments performed in duplicate $\left({ }^{*} \mathrm{p}<0.05,{ }^{*} \mathrm{p}<0.01\right.$, compared to control). 

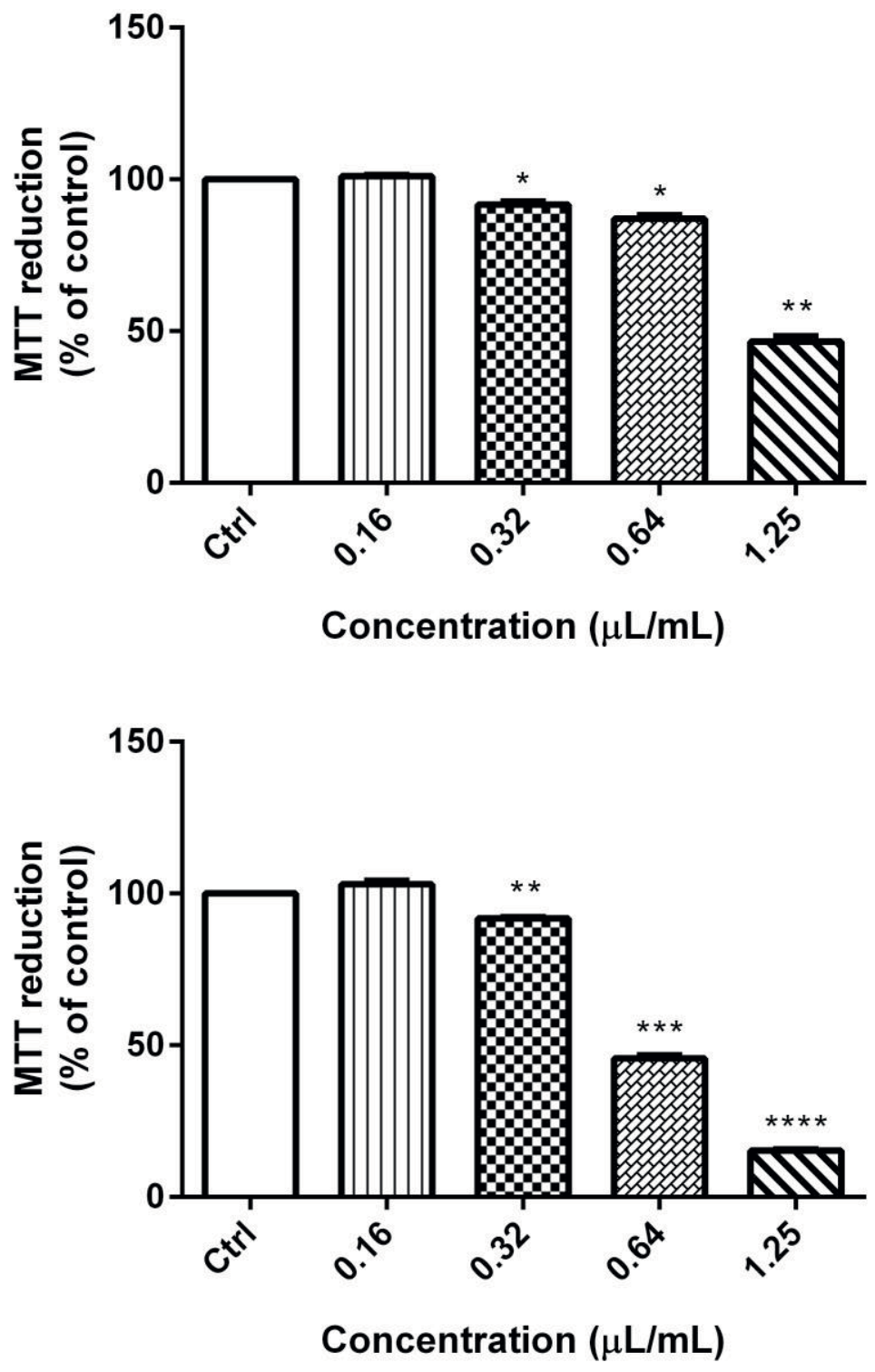

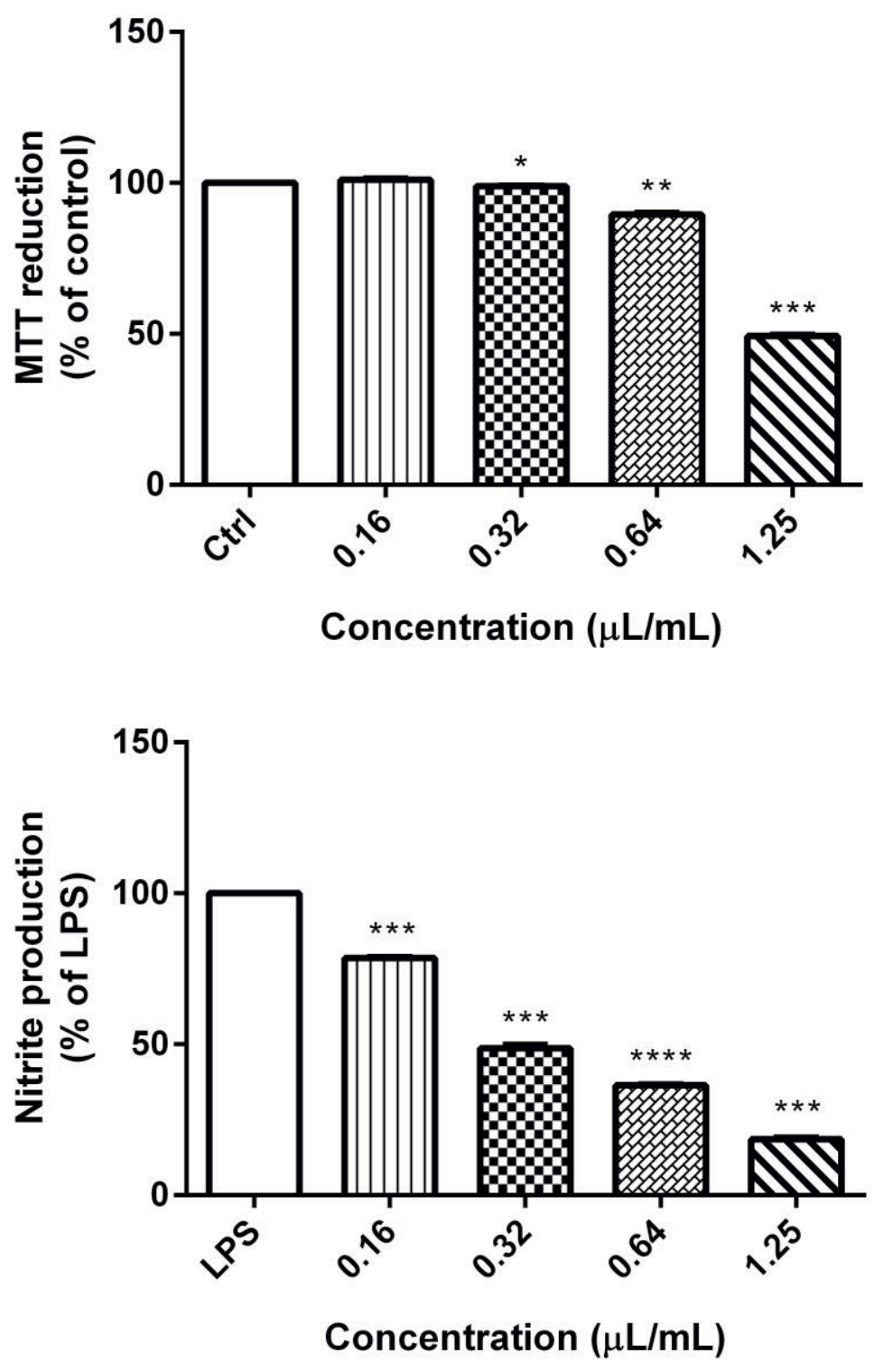


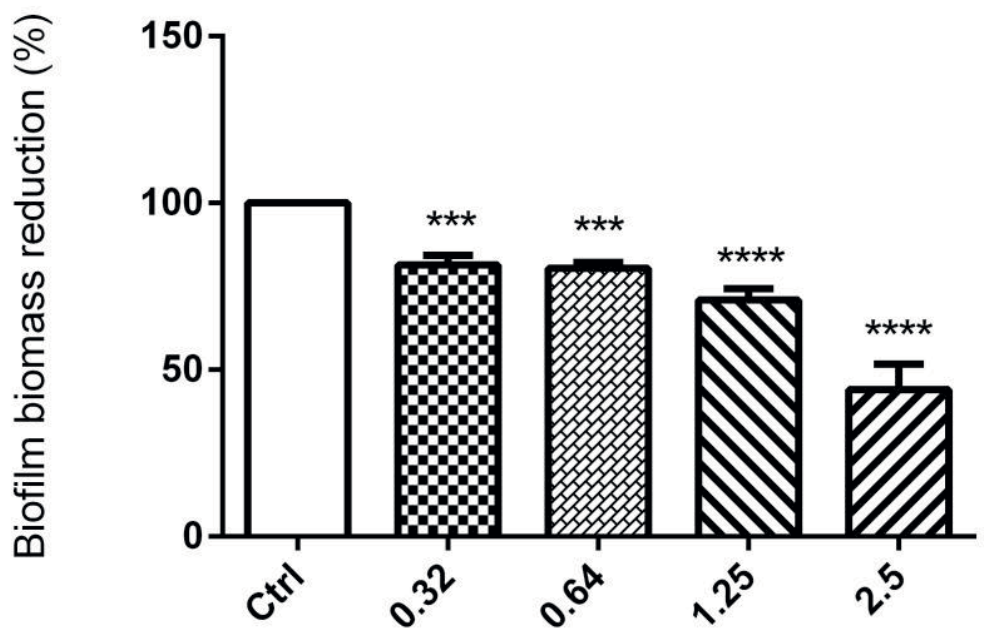

Concentration $(\mu \mathrm{L} / \mathrm{mL})$

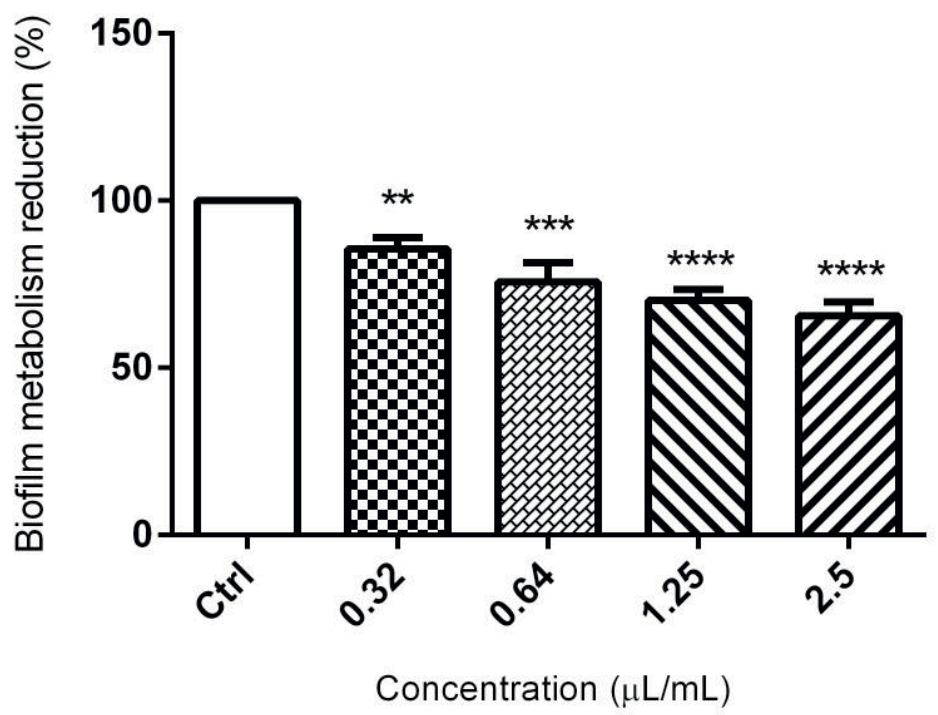




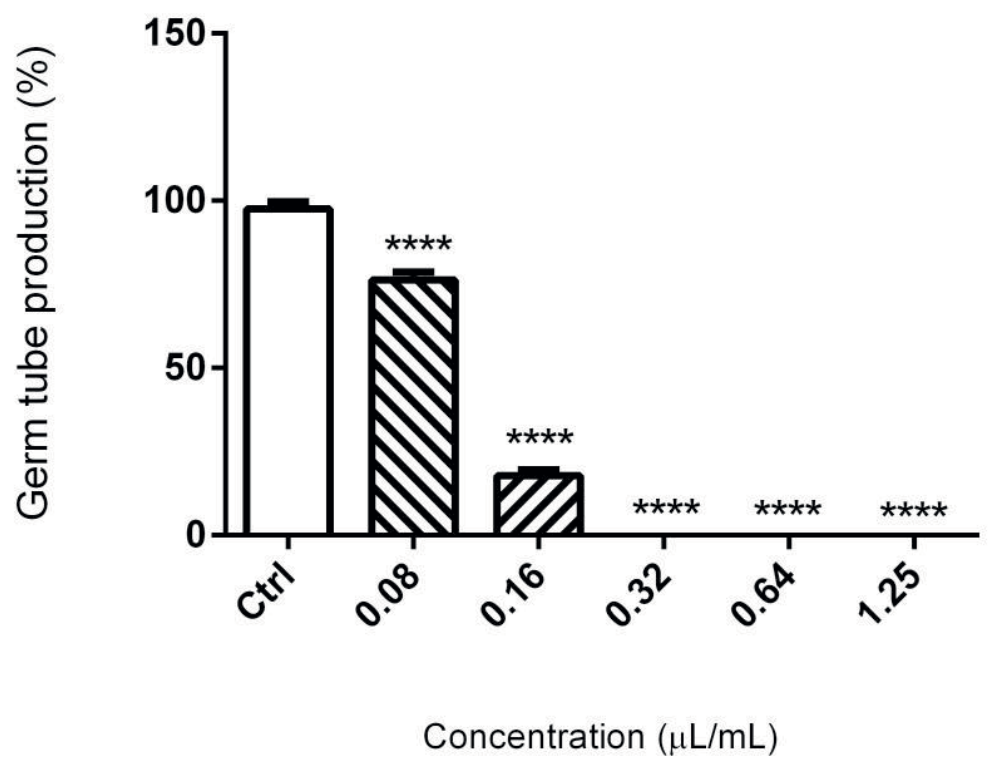



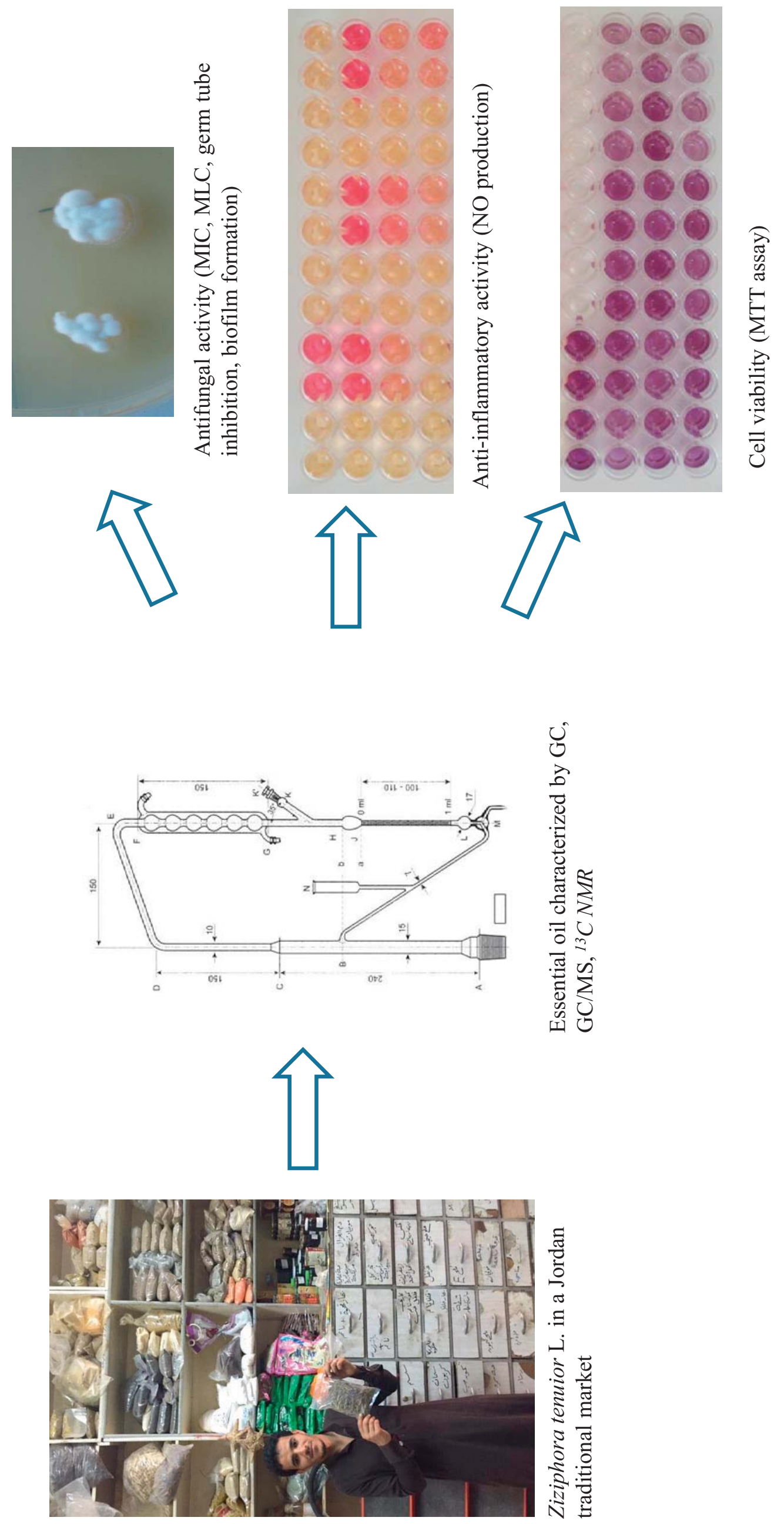